\title{
A systematic review of photovoice as participatory action research strategies
}

\author{
Nadi Suprapto ${ }^{1}$, Titin Sunarti ${ }^{2}$, Suliyanah $^{3}$, Desi Wulandari ${ }^{4}$, Hasan N. Hidayaatullaah ${ }^{5}$, \\ Alif S. Adam ${ }^{6}$, Husni Mubarok ${ }^{7}$ \\ 1,2,3,4,5,6,7 Physics Education Program, Universitas Negeri Surabaya, Indonesia \\ ${ }^{7}$ Graduate Institute of Digital Learning and Education, National Taiwan University of Science and Technology, Taiwan
}

\begin{tabular}{l} 
Article Info \\
\hline Article history: \\
Received Mar 10, 2020 \\
Revised Jul 11, 2020 \\
Accepted Aug 5, 2020 \\
\hline
\end{tabular}

\section{Keywords:}

Participatory action research

Photovoice

Qualitative inquiry

Systematic review

\begin{abstract}
Photovoice research is conducted by researchers to communicate images or photographs, and it has high confidence in analyzing the value, story or meaning of an image. Several previous studies that examined photovoice as a research strategy were analyzed and reviewed. This systematic review used an article selection process. It was defining the purpose, conducting a literature search, pulling articles by reading abstracts, reading the full paper, data abstraction, and conducting an analysis. The photovoice article selection was classified into education, health, and social science domain. Finally, forty-one articles have been reviewed with the total of participants involved ranged from five to fifty individuals. The majority of research method in the articles was participatory action research (PAR) through qualitative inquiry or field visits. Meanwhile, the research instruments used photography, documentation, observation, and interviews. In various fields of research, photovoice is able to increase the understanding of individuals or groups to interpret the content of an image or photo.
\end{abstract}

This is an open access article under the CC BY-SA license.

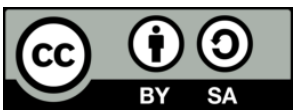

\section{Corresponding Author:}

Nadi Suprapto,

Physics Education Program,

Universitas Negeri Surabaya,

Jl. Ketintang, Surabaya 60231, Indonesia.

Email: nadisuprapto@unesa.ac.id

\section{INTRODUCTION}

From various studies, photovoice has been widely used as a method or strategy in problem-solving in the form of photography or documentaries, both educational, social, health and non-traditional literature using PAR (Participatory Action Research) [1, 2]. Wang stated that photovoice is the act of taking photos or documentation, followed by telling stories related to these photos [2, 3]. It is an approach as a means of gaining interest in research objects. The attraction of these objects makes it easier for readers or researchers to analyze events clearly and meaningfully so that they can increase researchers' responses [4]. Photovoice is a reinforcement or training technique to help communicate the contents of images and photos [5].

There are three objectives of photovoice [1], take notes and recorded the strengths and weaknesses of the environment around the individuals, to create dialogue by discussing groups about photographs, and to influence individual or group decision making. Through photovoice, students can revive the experience they have gained to be able to express strengths and weaknesses in the field visit program [6]. The initial step of the photovoice process is selecting the audience and creating groups [2]. When the process of forming groups has been made, then the next step gives direction on how to take photos properly. Photos that have been taken then analyzed according to the contents of the image and discussed with the audience [2]. The audience 
is allowed to be active in speaking out and having a definite opinion about the photo [7]. The success of photovoice depends on some factors, such as the nature of the phenomenon under investigation, time, period and audience interest in taking photos [7]. Photographs, documents, and photovoice can deliver the purpose of a story, science, knowledge, history, tradition, as well as social phenomena and other natural phenomena. In this way, photovoice can be used as an educational tool in the basic methods of learning [8].

Photovoice in the domain of learning makes students can feel directly and analyze comprehensively what they will learn. Outdoor learning and field trips serve as strategies for achieving knowledge and materials in photovoice [5, 6]. Therefore, photovoice is utilized as a way to research the domain of education. Through photovoice, students will be connected to science [9]. In addition to photovoice used in the area of education, photovoice is also able to be used in the social and health domain. In social domain, experiments carried out by members of three local temples through photographs and sounds have helped to give light on a religion that has been territorially misinterpreted [10]. Meanwhile, in health domain photovoice is a PAR strategy that contributes to discussing women's health $[1,2]$. In this explanation, it plays a role in the domain of research and learning.

A study of photovoice or photo-elicitation or photo novella is inseparable from the data collection process. The process was done in two ways, namely qualitative and quantitative method, or the combination of the two methods, which is called the mixed-method (the combination both of them). From the previous research discussed, it provides a picture of the condition of photovoice in describing health analysis using a qualitative method in the form of image and video descriptions [11]. Then, it is also mentioned in photovoice of educational research that is used as a qualitative method such as in pedagogy domain [12]. Taking, for example, a study by Cook \& Quigley employed 40 students as participatory action research (PAR) by using a qualitative method in conducting research and connecting students using photovoice [13].

Research about photovoice has been widely concerned by previous researchers from traditional photovoice in health study $[1,2,4,11,14-17]$ to psychology [18-20], education $[5,6,8,9,13,21-27]$, communication [28, 29], ethnicity [30], sport [31, 32], and management [7]. In this study, several previous pieces of research on photo-elicitation as a domain of case strategy will be analyzed and reviewed. Through the selection method, this research will be more focused. In general, the background of this research is used to find out how the overview of photovoice articles after reviewing several articles, investigating participant trends, analyzing research methods and instruments used in photovoice research. Figure 1 summarizes the photovoice as participatory action research strategies that guiding the previous researchers.

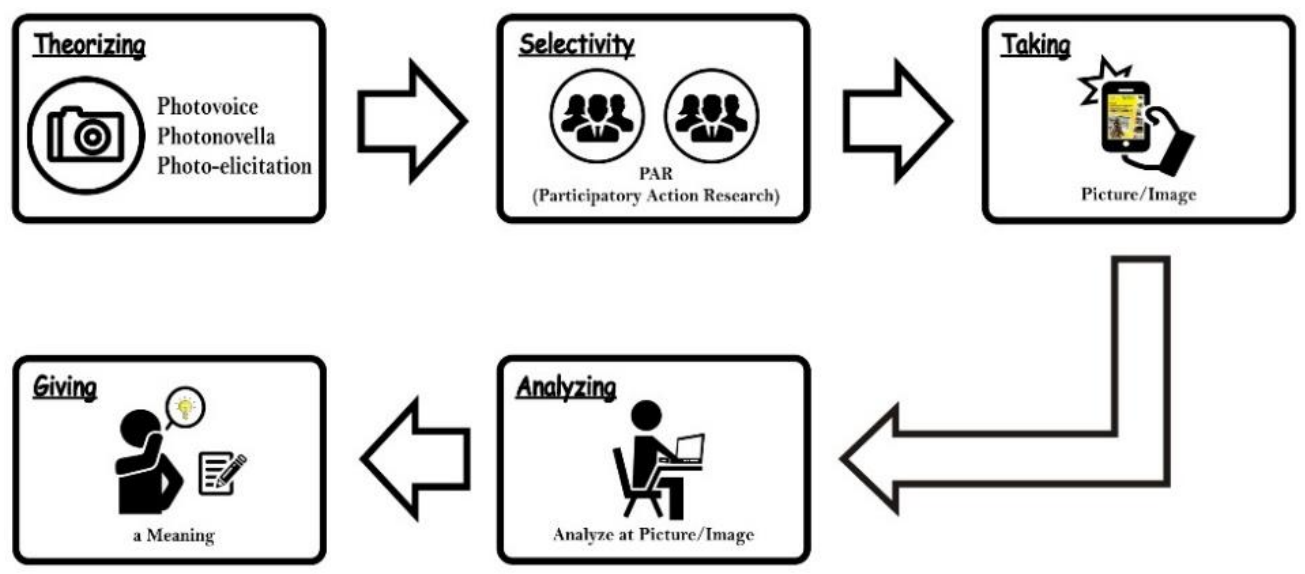

Figure 1. The scheme of photovoice as participatory action research strategies

\section{RESEARCH METHOD}

\subsection{The procedure of systematic review}

This research used the article selection method as guided by Suprapto \& Chang [33]. In selecting articles, it required certain procedures. In general, the articles were used all photovoice domains in various fields. This procedure followed the directions in Figure 2 [33]. This process begins by creating and defining research objectives and continuing to search for the word or sentence through literature search.

Figure 2 illustrates the schematic procedure of a systematic review of research. The systematic review process follows the direction of previous researchers [34-36]. The first steps are determining, creating, and defining the topic or idea that will be used to review the focus of the research. Then look for 
literacy or articles according to the topic of ideas to be used. When the article has been obtained, and then first read the article's abstract, and continues reading the whole article. By reading the article as a unit, researchers will be able to read the results of the research data and then analyze it according to the contents of the data.

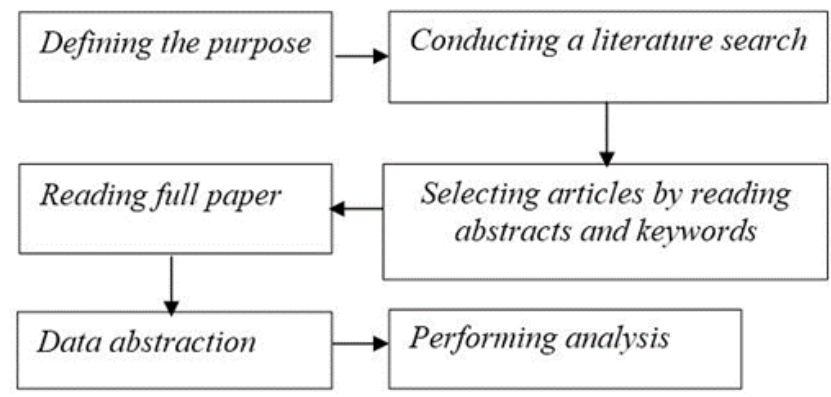

Figure 2. The procedure of systematic review

\subsection{Selection studies process}

After the photovoice articles were obtained, then there are four criteria for reviewing the article [33]. The first criterion is how the researcher selected the research participant. The second criterion is found and analyzed data. Meanwhile, the following two criteria are found out the methods and targets, and the photovoice field used in the research. In the fourth criterion, it can be interpreted that the photovoice field researched in the article belongs to the domain of education, social, health, tradition, or other areas of research. To identify photovoice as research strategies, it can be found in several research journals that are appropriate to their field. Here are a few samples of the names of research journals used: Journal of Women's Health, Journal of Creativity in Mental Health, Research in Science \& Technological Education, International Journal of Environmental \& Science Education, International Journal of Teaching and Learning in Higher Education, Journal of Prevention \& Intervention in the Community. Finally, forty-one articles were selected as the result of selection studies process.

Of the forty-one articles used as a review of photovoice, there were eight articles in the field of health studies [1, 2, 4, 11, 14-17], 16 articles in the field of education [5-9, 13, 20, 21, 23-27, 37-39], and 17 articles in the field of social research (including sport) [10,12, 18, 19, 28-32, 40-47]. Then, among this number of articles, we consider the number of representative sample in each domain for in-depth discussion: five articles in education, three articles in health studies and three articles in social studies. The following is a sample of the research that is referred to as the domain of education, social, and health science. Sample of papers were selected in this study as shown in Table 1.

Table 1. Sample of papers were selected in this study

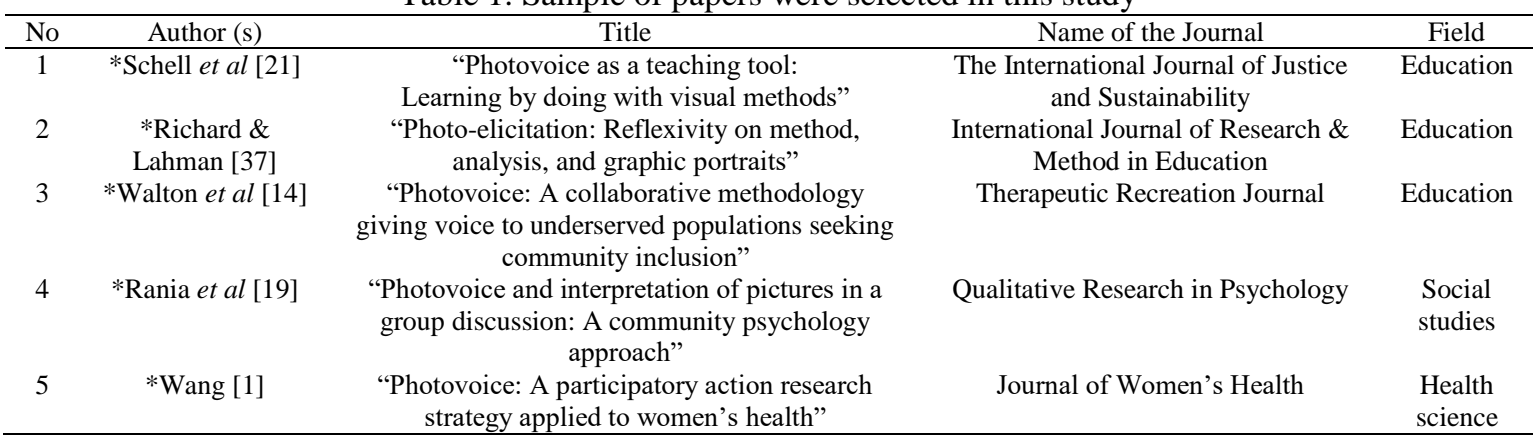

\section{RESULTS AND DISCUSSION}

From forty-one articles that have been selected and adjusted to the field of research, it obtained the total of articles in the social field greater than research in other fields. So in the discussion point, it will be analyzed in more detail how the instruments, data analysis, and research methods used in these types of articles. One article will be analyzed and then followed by another article. The common research method 
used in photovoice research is the qualitative method. One of them is an article from Schell, Ferguson, Hamoline, Shea, and Thomas-Maclean. The article was titled "Photovoice as a teaching tool: Learning by doing with visual methods". From this article, the problems obtained include: "How is the teaching and learning experience facilitated by the photovoice project in the methodology class?" In solving the research question, the qualitative method is used as a data collection process.

The participant of the research involved eleven college students: eight male and three female. These students have different age variations. Not only utilizing students as objects of research, but the authors also join in the process of collecting data in various scientific fields. It makes the research article unique. So the photovoice analysis is the result of taking pictures conducted by author and college students. Both the shooting in the fields of health, social, religious, and immigration as well as the response or impact experienced by a college student who acts as research objects and acts as researchers. Meanwhile, the research instruments used documentation study. Table 2 represents the sample of review results of the article in education domain that has been done out of sixteen articles (we choose 5 representative articles). It also explains the analysis of research objects, research methods, and research instruments from 5 selected photovoice articles.

Table 2. An overview of the educational articles' sample analyzed in this review

\begin{tabular}{|c|c|c|c|c|c|c|}
\hline \multirow{2}{*}{ No } & \multirow{2}{*}{ Author(s) } & \multirow{2}{*}{ Title } & \multicolumn{2}{|c|}{ Participant } & \multirow{2}{*}{$\begin{array}{c}\text { Research } \\
\text { methodology }\end{array}$} & \multirow{2}{*}{$\begin{array}{c}\text { Research } \\
\text { Instruments }\end{array}$} \\
\hline & & & Demography & Gender & & \\
\hline 1 & $\begin{array}{l}\text { *Schell et al } \\
{[21]}\end{array}$ & $\begin{array}{l}\text { "Photovoice as a } \\
\text { teaching tool: } \\
\text { Learning by doing } \\
\text { with visual methods" }\end{array}$ & $\begin{array}{l}\text { - Eleven } \\
\text { students from } \\
\text { different } \\
\text { studies } \\
\text { - four authors } \\
\text { of the article } \\
\text { (researchers) }\end{array}$ & $\begin{array}{l}\text { - Eight men } \\
\text { aged 20-30 } \\
\text { years, two } \\
\text { women aged } \\
\text { 31-40 years, } \\
\text { one female } \\
\text { aged } 41-50 \\
\text { years }\end{array}$ & $\begin{array}{l}\text { - Qualitative social } \\
\text { research } \\
\text { - Web } \\
\text { questionnaire }\end{array}$ & $\begin{array}{l}\text { - Image and } \\
\text { photo } \\
\text { documentation }\end{array}$ \\
\hline 2 & $\begin{array}{l}\text { *Richard \& } \\
\text { Lahman [37] }\end{array}$ & $\begin{array}{l}\text { "Photo-elicitation: } \\
\text { Reflexivity on method, } \\
\text { analysis, and graphic } \\
\text { portraits" }\end{array}$ & $\begin{array}{l}\text { - Nineteen } \\
\text { participants } \\
\text { in the } \\
\text { conference }\end{array}$ & $\begin{array}{l}\text { - Male } \\
\text { participants } \\
\text { aged 14-17 } \\
\text { years } \\
\text { - Nine female } \\
\text { participants } \\
\text { 12-16 years } \\
\text { old }\end{array}$ & $\begin{array}{l}\text { - Qualitative } \\
\text { inquiries } \\
\text { - Photo elicitation } \\
\text { - Analyzed } \\
\text { according to the } \\
\text { minds of the } \\
\text { researchers }\end{array}$ & $\begin{array}{l}\text { - Semi-structured } \\
\text { interviews } \\
\text { (either one-on- } \\
\text { one or focus } \\
\text { group) } \\
\text { - Observations } \\
\text { artifacts were } \\
\text { employed. }\end{array}$ \\
\hline 3 & $\begin{array}{l}\text { *Walton et al } \\
{[14]}\end{array}$ & $\begin{array}{l}\text { "Photovoice: A } \\
\text { collaborative } \\
\text { methodology giving } \\
\text { voice to underserved } \\
\text { populations seeking } \\
\text { community inclusion" }\end{array}$ & $\begin{array}{l}\text { - Twenty-two } \\
\text { communities } \\
\text { - Collaborate } \\
\text { with certain } \\
\text { universities } \\
\text { and } \\
\text { communities } \\
\text { ('Arc') }\end{array}$ & $\begin{array}{l}\text { - No } \\
\text { information } \\
\text { provided }\end{array}$ & $\begin{array}{l}\text { - Qualitative } \\
\text { metode } \\
\text { - PAR }\end{array}$ & $\begin{array}{l}\text { - Documentation } \\
\text { and } \\
\text { photography } \\
\text { - Exhibit the } \\
\text { results of group } \\
\text { discussions }\end{array}$ \\
\hline 4 & $\begin{array}{l}\text { *Rania et al } \\
{[19]}\end{array}$ & $\begin{array}{l}\text { "Photovoice as an } \\
\text { evaluation tool for } \\
\text { student learning on a } \\
\text { field trip" }\end{array}$ & $\begin{array}{l}\text { - Six students } \\
\text { from junior } \\
\text { high schools }\end{array}$ & $\begin{array}{l}\text { - Students } \\
\text { (male and } \\
\text { female) } \\
\text { - Four female } \\
\text { students } \\
\text { - Two male } \\
\text { students }\end{array}$ & $\begin{array}{l}\text { - Qualitative } \\
\text { methods } \\
\text { - Field trip } \\
\text { - Analysis of the } \\
\text { participatory } \\
\text { approach }\end{array}$ & $\begin{array}{l}\text { - Documentation } \\
\text { - Photography of } \\
\text { five selected } \\
\text { images } \\
\text { - Interviews are } \\
\text { represented by } \\
\text { one picture }\end{array}$ \\
\hline 5 & *Latz [42] & $\begin{array}{l}\text { Toward a new } \\
\text { conceptualization of } \\
\text { photovoice: Blending } \\
\text { the photographic as } \\
\text { method and self- } \\
\text { reflection }\end{array}$ & $\begin{array}{l}\text { - Seven } \\
\text { graduate } \\
\text { students in } \\
\text { coursework } \\
\text { institutions }\end{array}$ & $\begin{array}{l}\text { - Five female } \\
\text { students } \\
\text { - Two male } \\
\text { students }\end{array}$ & $\begin{array}{l}\text { - Qualitative } \\
\text { method } \\
\text { - Data analysis } \\
\text { using the } \\
\text { approach theory } \\
\text { ground } \\
\text { constructivist }\end{array}$ & $\begin{array}{l}\text { - Photography } \\
\text { - Documentation } \\
\text { - Interview } \\
\text { question } \\
\text { - SHOWeD } \\
\text { technique }\end{array}$ \\
\hline
\end{tabular}

Based on Table 2, the average participants involved in photovoice research were students, college students, and researchers themselves. The number of participants ranges from six to twenty-two individuals. Participant selection was made through the selection stage or direct selection by several samples, such as in the selection of classroom research samples. The majority of participants in photovoice articles are female. All papers on Table 2 used qualitative methods.

Research conducted by Schell et al. [21] indicated the use of social qualitative methods by utilizing the web as a tool to obtain information about how to photovoice procedures for taking pictures properly. 
Then the research used documentation instruments, photography, to make good object images. For other research, it was packaged using photo-elicitation, and the results of the images were analyzed according to the results of each individual's thoughts. This happened to the research described in Table 2, number 2 . The researcher used interviews with focus group discussion by nineteen participants who attended the conference. Discussions were held regarding shooting artefacts.

Furthermore, the results of the review article by Walton et al. [14], involving twenty-two participants in the periphery communities. These communities like "Arc" have collaborated with individual universities as a venue for the exhibition to be held at the end of the research process. In general, the participants involved female and male individuals. Still, in this research, it was not explained in detail how many women and men individuals were involved in the photovoice study. The involvement of these twentytwo communities did this research packaged in the form of Participation Action Research (PAR), which was then analyzed using qualitative methods. The process of taking data was done by documenting images and photos. After the data was obtained, then a group discussion was held to present the results of the photos or images that have been analyzed and will be exhibited at a special performance. The performance was attended by approximately one thousand people. The results presented in the production included sticky notes, comment cards, blackboard thoughts, and wall poster comments.

On the other hand, it has a small different from article number 1 . In the results of the article review number 4 from Table 2, it involved six students as participants from secondary school. This research was only focused on the smallest scale, both in the selection of participation, object images, and places used as field visits. By using qualitative methods and participatory approach analysis, the results of documentation obtained from the visit carried out among the biological field station. The focus of the picture taken was only five objects, and then only one sample was taken for the interview process. Then from the results obtained by the participants assessed and evaluated by researchers, the results of these studies improved the thinking skills of each participant.

After data and results were obtained, then it assessed and evaluated by researchers, to improve the thinking skills of each participant. The research was conducted by documenting self-awareness carried out by each student as a form of knowing the self-development they already have. The qualitative method was used as a way to analyze data in this study. The data obtained were analyzed using the ground constructivism approach, which was to create meaning from what has been learned by each participant. The research instrument used similar to the previous article, namely photography and documentation and then conducted interviews using the SHOWed technique.

From the results of reviewing five photovoice articles in the domain of education, it was found that the average participant involved six to twenty individual students, college students, and researchers or author articles. On the other hand, the majority of participants based on gender involved were women with ages ranging from twelve to fifty years. The research method used was a qualitative by utilizing documentation study, observation, and interviews.

Table 3 indicates the result of the photovoice article selection in the health field (three of the eight representative samples). The three articles were taken from international journals and conference, including the Journal of Women's Health, Journal of Creativity in Mental Health and Proceedings of the Annual International Conference Shia. The number of participants involved in the research was four individuals. The amount of a participant in a photovoice research in the health field was the health community member and also the doctors. Participants in the other two articles were not mentioned clearly. However, the three articles that were reviewed involved male and female.

Article of Wang involved participants in the Yunnan Women community. Through this participant, the appropriate research methodology is PAR by the community. The PAR included policymakers, leaders and members of the community. The instrument used to take pictures was modified in the form of interviews and also questionnaire questions. Questioner questions use semi-structural interviews or often referred to as SHOWeD. The procedure or process for finding images is obtained through the photovoice web.

Moreover, the review articles and research methods described by researchers in Table 3 number 2 used the literature review of sixteen articles by using qualitative methods. The research instrument was taken through databases such as CINAHL, Science Direct, and Proquest. Meanwhile, the explanation of research methods and instruments described in article number 3 was not much different from article number 1 . The results of the review of the article used a qualitative method by collecting photos and essay exam results both pre-comprehensive exams, during comprehensive or post-comprehensive exams.

The results of the photovoice review in the health domain were taken from three sample articles, as it explained in the previous paragraph. From the results of the analysis the participants involved were mostly from the general public. The total of participants was around fourteen to sixteen individuals. Participants in the research were not explained in detail. Then the research methodology used the PAR method, interviews, 
and literature review. The ordinary research instrument used documentation and interviews. After the researchers tabulated the results of samples from several articles in the domain of education and health, then this paper continued with the results of sample review articles in the area of social science. Table 4 illustrates a further explanation of social science articles in photovoice research.

Table 3. An overview of the health sample articles analyzed in this review

\begin{tabular}{|c|c|c|c|c|c|c|}
\hline \multirow{2}{*}{ No } & \multirow{2}{*}{ Author(s) } & \multirow{2}{*}{ Title } & \multicolumn{2}{|c|}{ Participant } & \multirow{2}{*}{$\begin{array}{c}\text { Research } \\
\text { Methodology }\end{array}$} & \multirow{2}{*}{ Intruments } \\
\hline & & & Dimension & Gender & & \\
\hline 1 & *Wang [1] & $\begin{array}{l}\text { "Photovoice: A } \\
\text { participatory action } \\
\text { research strategy } \\
\text { applied to women's } \\
\text { health" }\end{array}$ & $\begin{array}{ll}\text { - } & \text { Yunnan } \\
\text { women and } \\
\text { their kin } \\
\text { - Policy maker } \\
\text { - Leader and } \\
\text { member of } \\
\text { Community }\end{array}$ & $\begin{array}{c}\text { Men and } \\
\text { women }\end{array}$ & $\begin{array}{l}\text { - PAR } \\
\text { - Interview and } \\
\text { Question } \\
\text { - Literature } \\
\text { reviews } \\
\text { - Surveys }\end{array}$ & $\begin{array}{l}\text { - Semi-structural interview } \\
\text { (acronym SHOWeD) } \\
\text { - Assessment } \\
\text { - Asset mapping tools } \\
\text { - Participatory evaluation } \\
\text { - Web (www.photovoice.co) }\end{array}$ \\
\hline 2 & $\begin{array}{l}\text { *Hattakit \& } \\
\text { Wironpanic } \\
\text { h [11] }\end{array}$ & $\begin{array}{l}\text { "Photo-voice as a } \\
\text { qualitative research } \\
\text { method in } \\
\text { nursing and health } \\
\text { sciences: A literature } \\
\text { review" }\end{array}$ & 16 articles & - & Literature reviews & $\begin{array}{l}\text { - Retrieved from databases } \\
\text { such as CINAHL, } \\
\text { ScienceDirect and } \\
\text { Proquest. }\end{array}$ \\
\hline 3 & $\begin{array}{c}\text { *Koltz et al } \text {. } \\
{[15]}\end{array}$ & $\begin{array}{l}\text { "Picture perfect: Using } \\
\text { photo-voice to explore } \\
\text { four doctoral students" } \\
\text { comprehensive } \\
\text { examination } \\
\text { experiences" }\end{array}$ & $\begin{array}{c}\text { four } \\
\text { doctoral } \\
\text { students }\end{array}$ & - & $\begin{array}{l}\text { - Qualitative } \\
\text { research } \\
\text { descriptions and } \\
\text { extensive details } \\
\text { phenomenologica } \\
1 \text { methodology }\end{array}$ & $\begin{array}{l}\text { - Collecting photographs } \\
\text { - Essay exam } \\
\text { - Pre-comprehensive exam } \\
\text { - During comprehensive } \\
\text { exam } \\
\text { - Post comprehensive exam } \\
\text { - Photo-voice and journaling }\end{array}$ \\
\hline
\end{tabular}

Table 4. An overview of the social science sample articles analyzed in this review

\begin{tabular}{|c|c|c|c|c|c|c|}
\hline \multirow{2}{*}{ No } & \multirow{2}{*}{ Author(s) } & \multirow{2}{*}{ Title } & \multicolumn{2}{|c|}{ Participant } & \multirow{2}{*}{$\begin{array}{c}\text { Research } \\
\text { methodology }\end{array}$} & \multirow{2}{*}{ Intruments } \\
\hline & & & Demography & Gender & & \\
\hline 1 & $\begin{array}{l}\text { *Bennett \& } \\
\text { Dearden [40] }\end{array}$ & $\begin{array}{l}\text { "A picture of } \\
\text { change: Using } \\
\text { photovoice } \\
\text { to explore social } \\
\text { and environmental } \\
\text { change in coastal } \\
\text { communities on } \\
\text { the } \\
\text { Andaman Coast of } \\
\text { Thailand" }\end{array}$ & $\begin{array}{l}\text { - Coastal } \\
\text { communities } \\
\text { - Socioeconomic } \\
\text { groups } \\
\text { - Ethnicity } \\
\text { - Livelihood group } \\
\text { - Participant } 29 \\
\text { individuals }\end{array}$ & $\begin{array}{ll}\text { - } & \text { At Koh } \\
\text { Phrathong five } \\
\text { Females and } \\
\text { four mens } \\
\text { - At Baan Thao } \\
\text { Khao } 7 \text { women } \\
\text { and } 4 \text { man } \\
\text { - } \quad \text { In Baan Lions } \\
\text { and Tapae Yoi } \\
\text { - The age of } \\
\text { participants } \\
\text { ranged between } \\
20 \& 60+\text { years }\end{array}$ & $\begin{array}{l}\text { - Qualitative } \\
\text { Methodology } \\
\text { - By using a } \\
\text { combination of } \\
\text { snowballs } \\
\text { - Purposive } \\
\text { sampling } \\
\text { technique }\end{array}$ & $\begin{array}{l}\text { - Recruitment } \\
\text { and training } \\
\text { workshop } \\
\text { - Photography } \\
\text { assignment } \\
\text { - Narratives of } \\
\text { photographs } \\
\text { - Coding of } \\
\text { main topics } \\
\text { and themes } \\
\text { - Production and } \\
\text { co-editing of } \\
\text { book workshop }\end{array}$ \\
\hline 2 & $\begin{array}{l}\text { *Rania et al. } \\
{[19]}\end{array}$ & $\begin{array}{l}\text { "Photovoice and } \\
\text { interpretation of } \\
\text { pictures in a group } \\
\text { discussion: A } \\
\text { community } \\
\text { psychology } \\
\text { approach" }\end{array}$ & $\begin{array}{l}\text { - Community in } \\
\text { general }\end{array}$ & - & $\begin{array}{l}\text { - Focus group } \\
\text { qualitative } \\
\text { research } \\
\text { method } \\
\text { - PAR method } \\
\text { - One photo is } \\
\text { analyzed into } \\
\text { several } \\
\text { perceptions }\end{array}$ & $\begin{array}{l}\text { - Object Shoot } \\
\text { - Documentation } \\
\text { s } \\
\text { - SHOWed } \\
\text { technique } \\
\text { - Discussion }\end{array}$ \\
\hline 3 & *Sitter [41] & $\begin{array}{l}\text { "Taking a closer: } \\
\text { Look at } \\
\text { photovoice as } \\
\text { participatory } \\
\text { action research } \\
\text { method" }\end{array}$ & $\begin{array}{l}\text { - Researchers or } \\
\text { research views }\end{array}$ & $\begin{array}{l}\text { - Not explained in } \\
\text { detail }\end{array}$ & $\begin{array}{l}\text { - The qualitative } \\
\text { research. } \\
\text { - Using } \\
\text { photography \& } \\
\text { PAR }\end{array}$ & $\begin{array}{l}\text { Literature } \\
\text { review } \\
\text { photovoice }\end{array}$ \\
\hline
\end{tabular}

Based on Table 4, three sample photovoice researches were taken in the community or social domain. The above sample was taken from the International Journal of Justice and Sustainability, the Journal of Qualitative Research in Psychology, and the Journal of Progressive Human Services. Article number 1 in Table 4 has the purpose to analyze environmental and social changes based on photovoice. The research has also involved the seaside and coastal communities as participant objects in photovoice research by taking 
representative samples such as gender, social group, ethnicity, or livelihood group photovoice process involving twenty-nine participants. Of those participants, nine people were from Koh Phrathong, four people at Baan Lions, five people from Tapae Yoi and eleven people at Baan Tha Khao. The number of genders from the participant was balanced on average between men and women. This applies to the sample of research objects with a majority age of 40-60 years.

This study used qualitative methods with a combination of snowball techniques and purposive sampling. Using a snowball sampling technique means that the sample obtained was rotated from one respondent to another to explain the mindset in social change or environmental change [23-25, 40, 48]. Participants who have been selected are given guidance in the form of training in taking pictures or photos correctly, after that given the task of photography, and the results of the photos were then analyzed based on the results of the interview. This will be followed by coding the main topics and themes, and the outputs of the research will be produced and edited into a book to be used as implications or applications of environmental and social change conditions in the fisheries or marine environment [24, 25].

Meanwhile, article number 2 in Table 4 is an article entitled photovoice and interpretation of pictures in a group discussion. The article did not explain the participant subjects of the study thoroughly; it only mentioned the general community involved. Although, it specified the data collection using PAR, but it didn't explain subjectively participants who conducted the study. The article analyzed the features or images from the results of the photoshoot, then analyzed it based on the experience of each PAR. To analyze the picture, the research method used is a qualitative focus group discussion. The instrument in this study used documentation techniques. The photovoice process is almost the same as the other articles. In conducting the photovoice process, the initial step is to take a shot in the taking of the object image, then take a photo in a different period. Then another drawing object interviewed by the participant using the SHOWeD technique and discussed together with other participants. The object images obtained by each participant were analyzed with different experiences.

Meanwhile, article number 3 was a review of the article entitled taking a closer look at photovoice as a PAR method. In the research, the participant subjects used were the researchers or the views of the researchers. Because it was not explained in detail the gender involved as a participant, the researcher concluded that the gender used is male and female in general. The article's instrument used the literature review technique of various theories that underlie photovoice.

From the results of a review of three articles in the domain of social science, the average participant has taken the general public while specifically involving the participant from the marginal community-the number of participants' amount to nineteen individuals. However, the participants of the two research articles were not explained in detail. In addition, the number of genders between men and women on average was balanced. Like photovoice research in the domain of education and health, research methods in the domain of social sciences used qualitative methods. Meanwhile, the average instrument used SHOWed documentation and interview techniques. Through photovoice, the average research results obtained were close to the truth of the hypothesis, which was by the purpose of photovoice to improve understanding, and the level of one's critical thinking of images [9, 13, 42, 44, 46, 47, 49].

From the results of a review of forty-one articles about photovoice, almost all of them used qualitative methods. Participant or respondent research ranged from five until fifty individuals. In addition, the average instrument uses documentation, observation, interviews, and also presentations of views and analyzes that have been done. But there was a uniqueness of the article of Walton et al [14]: the observation instrument was packaged into an exhibition, just like an art exhibition. However, in various fields of research, the most researchers said that photovoice was able to increase the understanding of individuals or groups to interpret the content of an image or photo [22, 25, 46, 47, 50].

The photovoice method uniquely brings participants to capture their life through the lens of a camera while also allowing them to express emotions and to give meanings of their particular life situations [18, 27, 30, 46]. For further study, the researchers may modify the method and apply varying frameworks to increase relevance for varied participants [17, 23, 26, 43]. Specifically in education, the unique methods of photovoice are useful to promote the links between the school and home environments [24, 27, 38, 46]. Additionally, it has feasible to be implemented independently by teachers in the classroom. A photovoice project should be also intended to capture service learning through the students' perspectives and voices of a community [31, 41]. Among these possibilities of further study, there are three different sites of analytical attention in photovoice: "site of production, site of photo, and site of audiencing"; and three different modalities: "technological modality, compositional modality, and social modality" [39]. 


\section{CONCLUSION}

Based on the criteria in the selection study, conclusions can be drawn from how the researcher made sample selectivity, photovoice scales, participant analysis, and research methodology. First, through the selection of several articles, it was found that the general picture of photovoice was classified in the fields of education, health, and social science. Second, from the results of the forty-one review articles, the total of participants or respondents used in the photovoice study was ranged from five to fifty individuals. In the domain of education involving six to twenty participants, with the target includes students and students, and author articles. In the health domain involved four individuals, including policymakers, leaders, and community members. On the other hand, the domain of social science involved nineteen individuals, including marginal communities and other social communities. Third, overall the research methodology that often used was qualitative methods, whether through qualitative social research, qualitative investigations, PAR methods, or field trips. Photovoice was also increased the understanding of individuals or groups to interpret the content of an image or photo.

\section{REFERENCES}

[1] C.C. Wang, "Photovoice: A Participatory Action Research Strategy Applied to Women's Health," Journal of Woment's Health, vol. 08, no. 2, pp. 185-192, 1999.

[2] C.C. Wang, "Youth Participation in Photovoice as a Strategy for Community Change," Journal of Community Practice, vol. 14, no. 1/2, pp. 147-161, 2006.

[3] P. Beverly, B. Krieg, L. Murdock and J. Havelock, "A Practical Guide to Photovoice: Sharing Pictures, Telling Stories and Changing Communities," Canada: The Prairie Women's Health Centre of Excellence, Winnipeg, Manitoba, 2009.

[4] G. Riley, and E. Manias, "The Uses of Photography in Clinical Nursing Practice and Research: A Literature Review," Journal of Advanced Nursing, vol. 48, no. 04, pp. 397-405, 2004.

[5] M. Behrendt and K. Machtmes, "Photovoice as an Evaluation Tool for Student Learning on a Field Trip," Research in Science \& Techological Education, vol. 34, no. 2, pp. 187-203 2016.

[6] M. Behrendt and T. Franklin, "A Review of Research on School Field Trips and Their Value in Education," International Journal of Environmental and Science Education, vol. 9, no. 3, pp. 235-245, 2004.

[7] V. Chio and P. Fandt, "Photovoice in the Diversity Classroom: Engagement, Voice and the 'Eye/I' of the Camera," Journal of Management Education, vol. 31, no. 4, pp. 484-504, 2007.

[8] N. Manohar, D. Berkowitz, J. Wilder, and J. Tinkler, "Photovoice: A Critical Pedagogical Assignment in the Sociology Classroom," Currents in Teaching and Learning, vol. 5, no. 1/2, pp. 36-51, 2013.

[9] K. Cook and C. Quigley, "Connecting to Our Community: Utilizing Photovoice as a Pedagogical Tool to Connect College Students to Science," International Journal of Environmental and Science Education, vol. 8, no. 2, pp. 339-357, 2013.

[10] J.M. Eric, "Visual "Voodoo": Photo-Voice in Togo," Visual Anthropology, vol. 30, no. 4, pp. 287-309, 2017.

[11] A.U. Hattakit and W. Wironpanich, "Photo-voice as a Qualitative Research Method in Nursing and Health Sciences: A literature Review," Proceedings of The Annual International Conference Syiah Kuala University, vol. 1, no. 1, pp.163-171, 2011.

[12] C. Mulder and A. Dull, "Facilitating Self-Reflection the Integration of Photovoice in Graduate Social Work Education," Social Work Education, vol. 33, no. 8, pp. 1017-1036, 2014.

[13] K. Cook, "Grappling with Wicked Problems Exploring Photovoice as a Decolonizing Methodology in Science Education," Cultural Study of Science Education, vol. 10, pp. 581-592, Jul 2015.

[14] G. Walton, S.J. Schleien, L.R. Brake, C.C. Trovato and T. Oakes, "Photovoice A Collaborative Methodology Giving Voice to Underserved Populations Seeking Community Inclusion,” Therapeutic Recreation Journal, vol. 66, no. 3, pp. 168-178, 2012.

[15] R.L. Koltz, et al., "Picture Perfect Using Photo-Voice to Explore Four Doctoral Students' Comprehensive Examination Experiences," Journal of Creativity in Mental Health, vol. 5, no. 4, pp. 389-411, 2010.

[16] T. Golden, "Reframing Photovoice: Building on the Method to Develop More Equitable and Responsive Research Practices," Qualitative Health Research, vol. 30, no. 6, pp. 960-972, 2020.

[17] E.M. Carr, G.D. Zhang, J.Y. Ming and Z.S. Siddiqui, "Qualitative research: An overview of emerging approaches for data collection,” Australasian Psychiatry, vol. 27, no. 3, pp. 307-3091, 2019.

[18] V. C. Sekaran, A. Bailey, V.G. Kamath, L. Ashok and A. Kamath, "'This is the place where I can be alone, no tension:' Photovoice evidence for adolescent perceptions of their microsystem and psychological adjustment," Asian Journal of Psychiatry, vol. 51, p. 102021, Mar 2020.

[19] N. Rania, et al., "Photovoice and Interpretation of Pictures in a Group Discussion a Community Psychology Approach," Qualitative Research in Psychology, vol. 12, no. 4, pp. 382-396, 2015.

[20] L.F. Lichty, "Photovoice as a Pedagogical Tool in the Community Psychology Classroom," Journal of Prevention \& Intervention in the Community, vol. 41, no. 2, pp. 89-96, 2013.

[21] K. Schell, A. Ferguson, R. Hamoline, J. Shea and R. Thomas-Maclean., "Photovoice as a Teaching Tool Learning by Doing with Visual Methods," International Journal of Teaching and Learning in Higher Education, vol. 21, no. 3, pp. 340-352, 2009. 
[22] T. Sunarti, H. Mubarok, Suliyanah, A. S. Adam and N. Suprapto, "Pre-service Physics Teachers' Experiences of Being Member of Photovoice Project," Journal of Physics Conference Series, vol. 1351, no. 012062, pp. 1-6, 2019.

[23] V. Derr and J.A. Simons, "A review of photovoice applications in environment, sustainability, and conservation contexts: Is the method maintaining its emancipatory intents?" Environmental Education Research, vol. 26, no. 3, pp. 359-380, 2020.

[24] C.G.P. Berdanier and M.F. Cox, "Research and assessment of learning environments through photoelicitation: Graduate student perceptions of electronics manufacturing in India," Advances in Engineering Education, vol. 4 , no. 4, p. 24, 2015.

[25] L.B. Cole and E. Altenburger, "Framing the Teaching Green Building: Environmental education through multiple channels in the school environment," Environmental Education Research, vol. 25, no. 11, pp. 1654-1673, 2019.

[26] M. Call-Cummings, M. Hauber-Özer, C. Byers and G.P. Mancuso, "The power of/in Photovoice," International Journal of Research and Method in Education, vol. 42, no. 4, pp. 399-413, 2019.

[27] M. Verdonck, R. Greenaway, A. Kennedy-Behr and E. Askew, "Student experiences of learning in a technologyenabled learning space," Innovations in Education and Teaching International, vol. 56, no. 3, pp. 270-281, 2019.

[28] P.E. Wagner, "Picture perfect bodies: Visualizing hegemonic masculinities produced for/by male fitness spaces," International Journal of Men's Health, vol. 15, no. 3, pp. 235-258, 2016.

[29] P.E. Wagner, et al., "Pictures, Patience, and Practicalities Lessons Learned from Using Photovoice in Applied Communication Contexts," Journal of Applied Communication Research, vol. 44, no. 3, pp. 336-342, 2016.

[30] K. Kokka and T. Chao, "How I show up for Brown and Black students': Asian American male mathematics teachers seeking solidarity," Race Ethnicity and Education, vol. 23, no. 3, pp. 432-453, 2020.

[31] J.E. Johnson, "Project L.E.E.P. (Leadership through Education, Experience and Photovoice): An embedded graduate service-learning initiative," Sport Management Education Journal, vol. 14, no. 1, pp. 55-57, 2020.

[32] D.B. Robinson, I.M. Robinson, V. Currie and N. Hall, "The Syrian Canadian Sports Club: A community-based participatory action research project with/for Syrian Youth Refugees," Social Sciences, vol. 8, no. 6, p. 163, 2019.

[33] N. Suprapto and T.-S. Chang, "Research on University Student's Self-Efficacy Scale in Science Education: A Systematic Review," Proceeding of the IConSSE FSM SWCU, pp. 120-129, 2015.

[34] N. Suprapto, "What should Educational Reform in Indonesia look like?"- Learning from the PISA Science Scores of East-Asian Countries and Singapore," Asia Pacific Forum on Science Learning and Teaching, vol. 17, no. 2, pp. 1-21, 2016.

[35] N. Suprapto, W.-Y. Liu and C.-H. Ku, "The Implementation of Multiple Intelligence in (Science) Classroom: From Empirical into Critical," Pedagogika, vol. 126, no. 2, pp. 214-227, 2017.

[36] N. Suprapto and Y.-F Pai, "Promoting Science Centers by Using MOOCs: Model for Communicating Informal Science Education," Man in India, vol. 95, no. 4, pp. 1005-1012, 2015.

[37] V.M. Richard and M.K.E. Lahman, "Photo-elicitation Reflexivity on Method, Analysis, and Graphic Portraits," International Journal of Research and Method in Education, vol. 38, no. 1, pp. 3-22, 2015.

[38] C. McKernan, D. Gleddie and K. Storey, "Student-centred photovoice as a mechanism for home-school interaction: Teacher perceptions of efficacy," Health Education Journal, vol. 79, no. 1, pp. 82-93, 2020.

[39] Q. Wang and K. Hannes, "Toward a More Comprehensive Type of Analysis in Photovoice Research: The Development and Illustration of Supportive Question Matrices for Research Teams," International Journal of Qualitative Methods, vol. 19, pp. 1-15, Jan 2020.

[40] N.J. Bennett and P. Dearden, "A picture of change: using photovoice to explore social and environmental change in coastal communities on the Andaman Coast of Thailand," Local Environment: The International Journal of Justice and Sustainability, vol. 18, no. 9, pp. 983-1001, 2013.

[41] K.C. Sitter, "Taking a Closer Look at Photovoice as a Participatory Action Research Method," Journal of Progressive Human Services, vol. 28, no. 1, pp. 36-48, 2017.

[42] A.O. Latz, "Toward a New Conceptualization of Photovoice Blending the Photographic as Method and SelfReflection," Journal of Visual Literacy, vol. 31, no. 2, pp. 49-70, 2012.

[43] S.-H. Kim, J. Canfield and D. Harley, "Using Photovoice as a method to examine microaggressions: Conceptualizing culturally competent practice and curriculum with Asian Americans," Journal of Human Behavior in the Social Environment, vol. 29, no. 8, pp. 1036-1043, 2019.

[44] S. Tickle, "Engaging young people through photovoice in coastal resorts," Qualitative Research Journal, vol. 20, no. 1, pp. 103-1151, 2019.

[45] A.T. Rogers, B. Braband and R. Gaudino, "Implementing the Pedagogy of Suffering: A Photovoice Innovation in Students' Exploration of Grief and Loss," Journal of Social Work Education, vol. 55, no. 4, pp. 684-694, 2019.

[46] I. Eisen, B.J. Cunningham and W. Campbell, "Conducting participatory photography with children with disabilities: A literature review," Disability and Rehabilitation, vol. 41, no. 16, pp. 1943-1954, 2019.

[47] V. Lam, K. Romses and K. Renwick, "Exploring the relationship between school gardens, food literacy and mental well-being in youths using photovoice," Nutrients, vol. 11, no. 6, Article number 1354, pp. 1-10, 2019.

[48] W. L. Neuman, Social Research Methods: Qualitative and Quantitative Approaches, 4th Edition. Boston, MA: Allyn and Bacon, 2000.

[49] L. Manasia, "From Community to Individual: Re-thinking Photovoice Methodology for Education Research," Education World 2016 7th International Conference, pp. 450-459, 2017.

[50] N. Suprapto, et al., "Essential Factors Influencing Preparation of Physics Laboratory in New Curriculum: Photo Voice Study," Journal of Physics Conference Series, vol. 1351, no. 012063, pp. 1-7, 2019. 